\title{
Evaluation of the Yamaguchi University Self-Assessment and Evaluation System and Its Improvement
}

\author{
Kahori Ogashiwa *, Takahiro Matsumoto ${ }^{\dagger}$, \\ Yue Wang ${ }^{\dagger}$, Joji Kariya ${ }^{\dagger}$, Hiroo Naitoh ${ }^{\dagger}$
}

\begin{abstract}
University evaluation is mandated by the School Education Act and the National University Corporation Act. Being educational organizations, universities are currently required to conduct self-assessment measures and institute upgrades. Yamaguchi University introduced the Yamaguchi University Self-Assessment and Evaluation System (YUSE) before the incorporation of national universities, and the system has been in operation and undergone improvements for over a decade. The present paper reports an overview of the portal site and the three web systems of Yamaguchi University pertaining to self-assessment. It also outlines the improvements effected to the current assessment system based on user requests. These advances will provide useful information to enhance evaluation systems at other universities. The stated enhancements can be categorized into three frameworks related to the systematic issues and that have been changed for the better: "system usability," "links to other systems," and "visualization functions (graphs) for analyses." The present study will be useful not only as a fundamental material for future activities related to university evaluation and institutional research, but also as a comparative content for the evaluation support systems at other universities.
\end{abstract}

Keywords: University Evaluation, Institutional Research, Self-Assessment and Evaluation System.

\section{Introduction}

University evaluation is mandated by the School Education Act and the National University Corporation Act. National universities were incorporated in 2004, and since then, Japanese institutions of higher education were obliged to undertake a certified evaluation and accreditation program every seven years. They were required to conduct self-assessments and make organizational improvements. To establish internal quality assurance, many universities have introduced institutional research aimed at constructing data-based mechanisms for evaluation and improvement [1][2][3][4][5].

\footnotetext{
${ }^{*}$ Teikyo University, Japan

$\dagger$ Yamaguchi University, Japan
} 
For example, Yamaguchi University introduced the Yamaguchi University Self-Assessment and Evaluation System (YUSE) even before the incorporation of national universities, and this system has been in operation and has undergone improvements for over a decade [6]. A new self-assessment and evaluation system was developed during this process, and is currently being employed throughout the organization.

\section{Yamaguchi University Self-Assessment and Evaluation Sys- tem}

\subsection{System overview}

This section provides an overview of the new YUSE (YUSE/TNG).

Figure 1 shows the web system that performs the self-assessment and evaluation task at Yamaguchi University and depicts the process flow [7]. The Yamaguchi University Self-Assessment and Evaluation System comprises a portal site and three web systems for the following: (1) the self-assessment and evaluation of faculty members, (2) information of the organization's activities, and (3) the self-assessment and evaluation of department chairs. In addition, we have a portal site that aggregates the three systems.

Each faculty member enters the status of their educational activities and research activities, performing a self-assessment in (1). The data entered in (1) is aggregated in (2) for each organization to clarify organizational trends and challenges. Thereafter, a comparative analysis is conducted with other departments. In (3), analyses of affiliated departments are completed with reference to the data aggregated in (2). Based on these self-assessment results, Yamaguchi University announces the state of its activities in the "Yamaguchi University Report" [8].

The self-assessment and evaluation system currently in use has been improved in accordance with the purpose of its use and in response to user requests. We explore these improvements through a scrutiny of the self-assessment and evaluation system at Yamaguchi University and an analysis of user requests. A questionnaire system was also constructed in addition to the three systems and the portal site mentioned above [9].

\subsection{System for the self-assessment and evaluation of faculty members}

Data input and its continuous accumulation were important functions in the old version of YUSE. However, in YUSE/TNG (the new version) the principal functions are the input of statistical values, the computation of indices, and the support of various evaluation processes using such indices. Data sources for statistical values become electronic syllabus systems and faculty databases, but a deliberate cross-system collaboration was not conducted in the first year of the implementation of evaluation. In other words, a link to the data reading screen of the other system was presented and the statistical values were entered one by one. We considered changing the processing method so that for some statistical values the calculation of the items from the faculty database is accomplished from the raw data dumped in the CSV format. In addition, it became possible to check an instructor's lecture information by linking it with the course evaluation system (IYOCAN) (link function). These functions were developed in the new system (Figure 2, Figure 3). 


\section{University-wide PDCA system in Yamaguchi University}

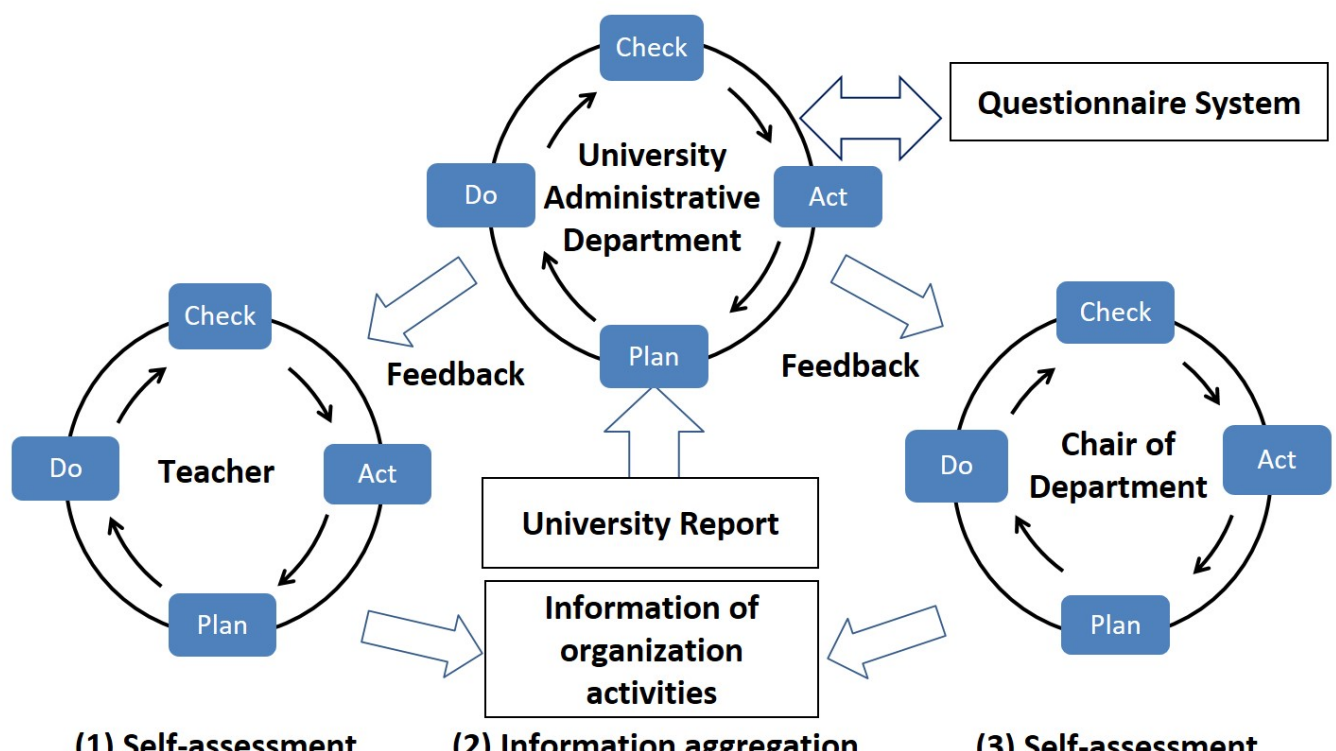

(1) Self-assessment

(2) Information aggregation

(3) Self-assessment

Figure 1: Flow of self-assessment and evaluation at Yamaguchi University [7].

\begin{tabular}{|c|c|c|c|c|c|c|c|}
\hline \multicolumn{8}{|l|}{ 目次 } \\
\hline 登舒顓目 & 登银数 & 合計㛲 & & & & & \\
\hline e1_1 担当科目 & 0 & & & & & & \\
\hline r1_1 雑誌碖文 & 1 & & & & & & \\
\hline $\mathrm{r} 1 \_$2著書 & 0 & & & & & & \\
\hline $\mathrm{r1} 13$ 解説·事例報告·フロシーデイノグス等 & 0 & & & & & & \\
\hline $\mathrm{r} 1$ _4 学会等発表 & 1 & & & & & & \\
\hline r1_5受賞 & 0 & & & & & & \\
\hline r1_6知的財産の形成 & 0 & & & & & & \\
\hline r1_7 その他, 研究·含造(関する活動 & 0 & & & & & & \\
\hline r2_2 科学研究费獾得 & 1 & $14,700,000$ & & & & & \\
\hline r2_3 その他の外部資金偡得 & 0 & 0 & & & & & \\
\hline r2_4 等付金 & 0 & 0 & & & & & \\
\hline r3_1 (a) 共同研究 & 0 & & & & & & \\
\hline r3_1 (b) 受乱研究 & 0 & & & & & & \\
\hline \multicolumn{8}{|l|}{ e1_1 担当科目 } \\
\hline \multicolumn{8}{|l|}{ データ登録がありません。 } \\
\hline \multicolumn{8}{|l|}{ r1_1 雑誌論文 } \\
\hline \multicolumn{8}{|l|}{ 1 件あります. } \\
\hline \multicolumn{3}{|c|}{ 諭文名 } & 种誌名 & Vol. & No. & 出版年月 & pp. \\
\hline \multicolumn{8}{|l|}{ r1_2 著書 } \\
\hline \multicolumn{3}{|l|}{ データ登録がありません。 } & & & & & \\
\hline
\end{tabular}

Figure 2: Data reference screen from the faculty database. 


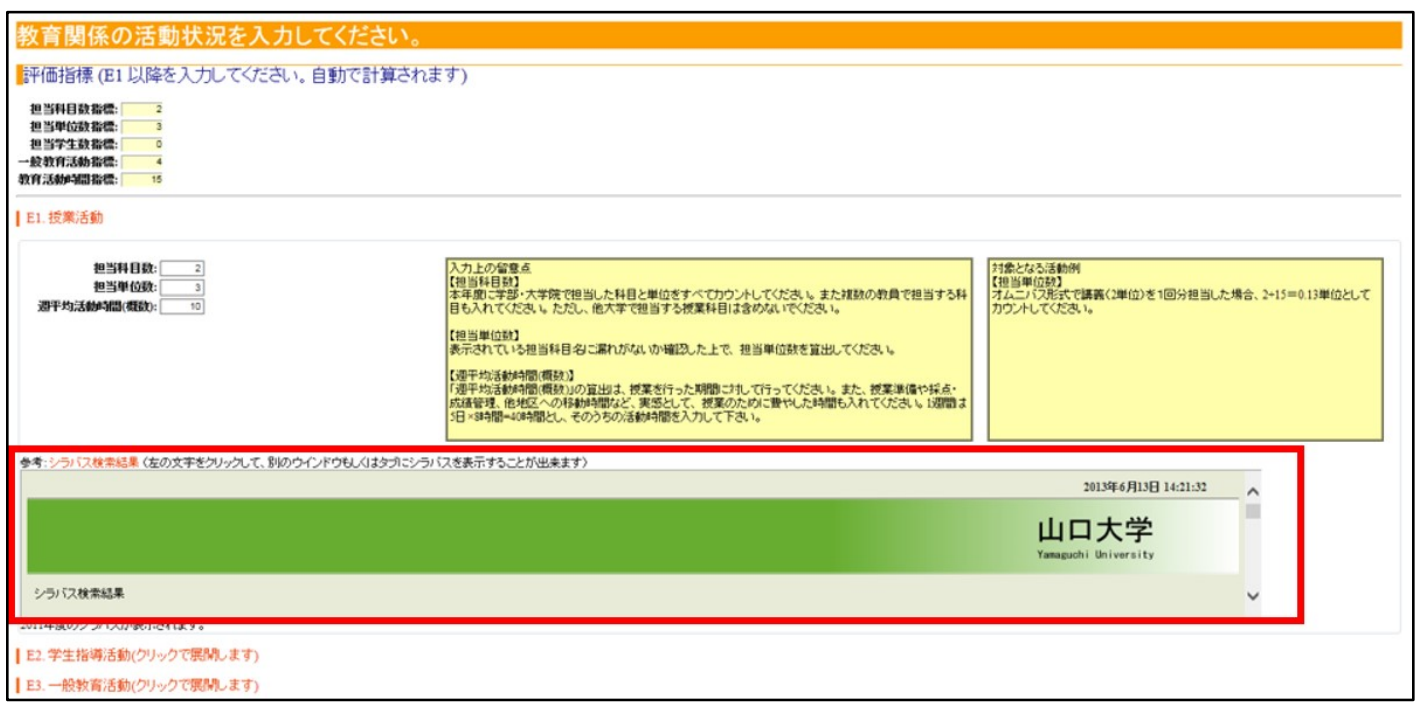

Figure 3: Data reference screen from the course evaluation system.

Figure 4 (a, b, c, and d) shows a part of the self-assessment and evaluation screen. It is not merely a display of index data, and if available, it also makes comparisons with the previous year's organizational values and index data. The organizational definition for the purpose of comparison is prepared in (a). It is possible to define values by taking the academic department or subject as the base, and by arbitrarily combining the union and intersection of sets with the difference set. In addition, there is a questionnaire screen to fill in opinions addressed to the university evaluation department and to the head of the department.

\section{組織の選択

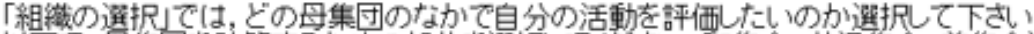 \\ 以下て, 母果団を計算するたゆの操作を迭抓してくたさい, 和集合, 共通集合, 差集合演算力使えます。

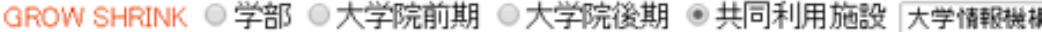 \\ 斜䋘容磪定 \\ 共同, 大学情垠機蔽.全て選报}

(a) Definition of organizations to be compared for self-assessment. 


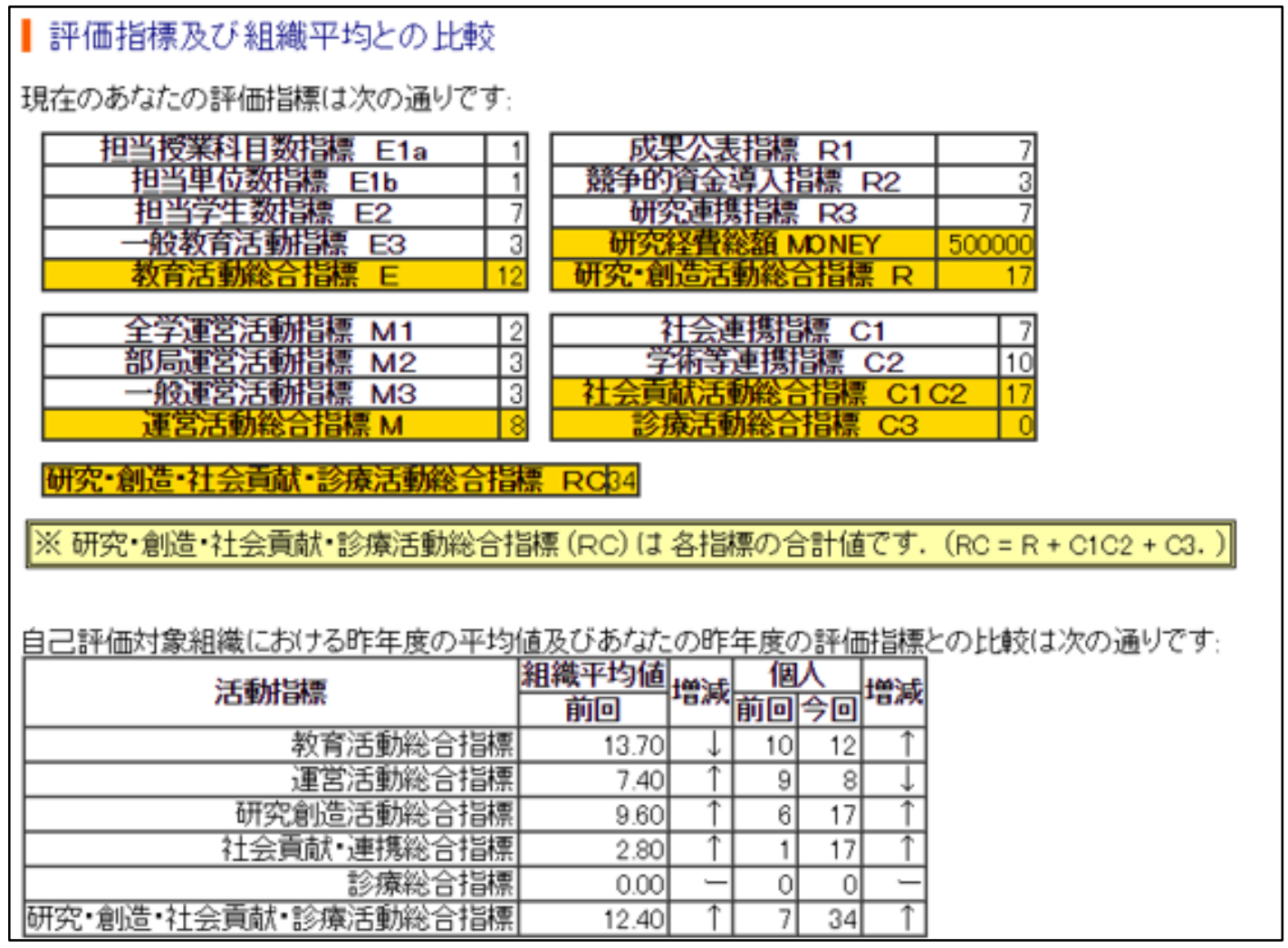

(b) A comparison of own evaluation index value for this year and own evaluation index value for the previous year.

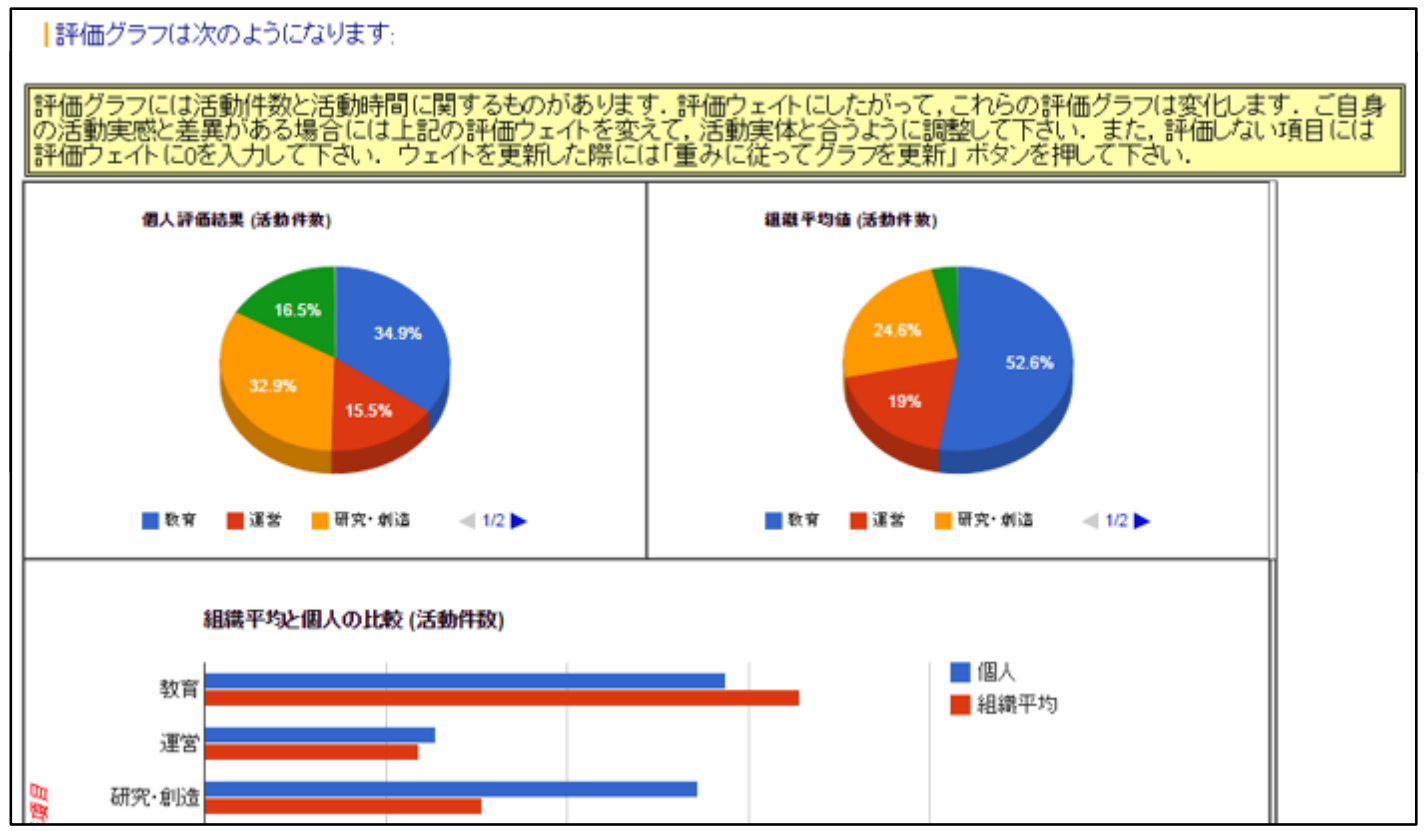

(c) A comparison between own evaluation index value and the organizational average. 


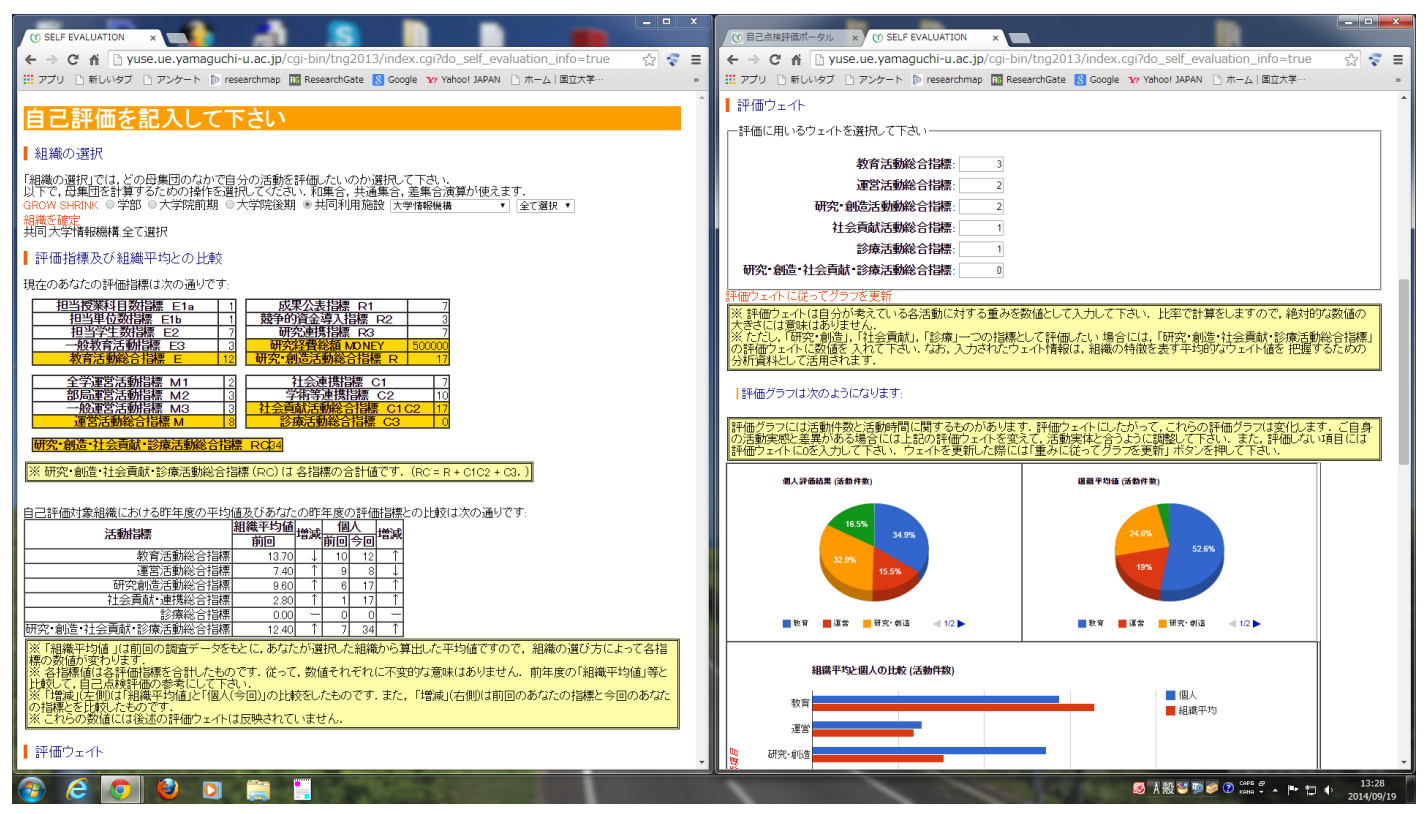

(d) A sample screen capture of the system

Figure 4: Self-assessment and evaluation system screen in YUSE/TNG (the new version).

\subsection{System for information on the organization's activities}

In the above-mentioned self-assessment and evaluation by individuals, it is possible to compare the index value of a specific set and the own index value. However, in the Organizational Activities Information Aggregation System, it is possible to compare the functions of each item by organization as well as between organizations in various fields. A screen aggregating the activities of a department is shown in Figure 5.

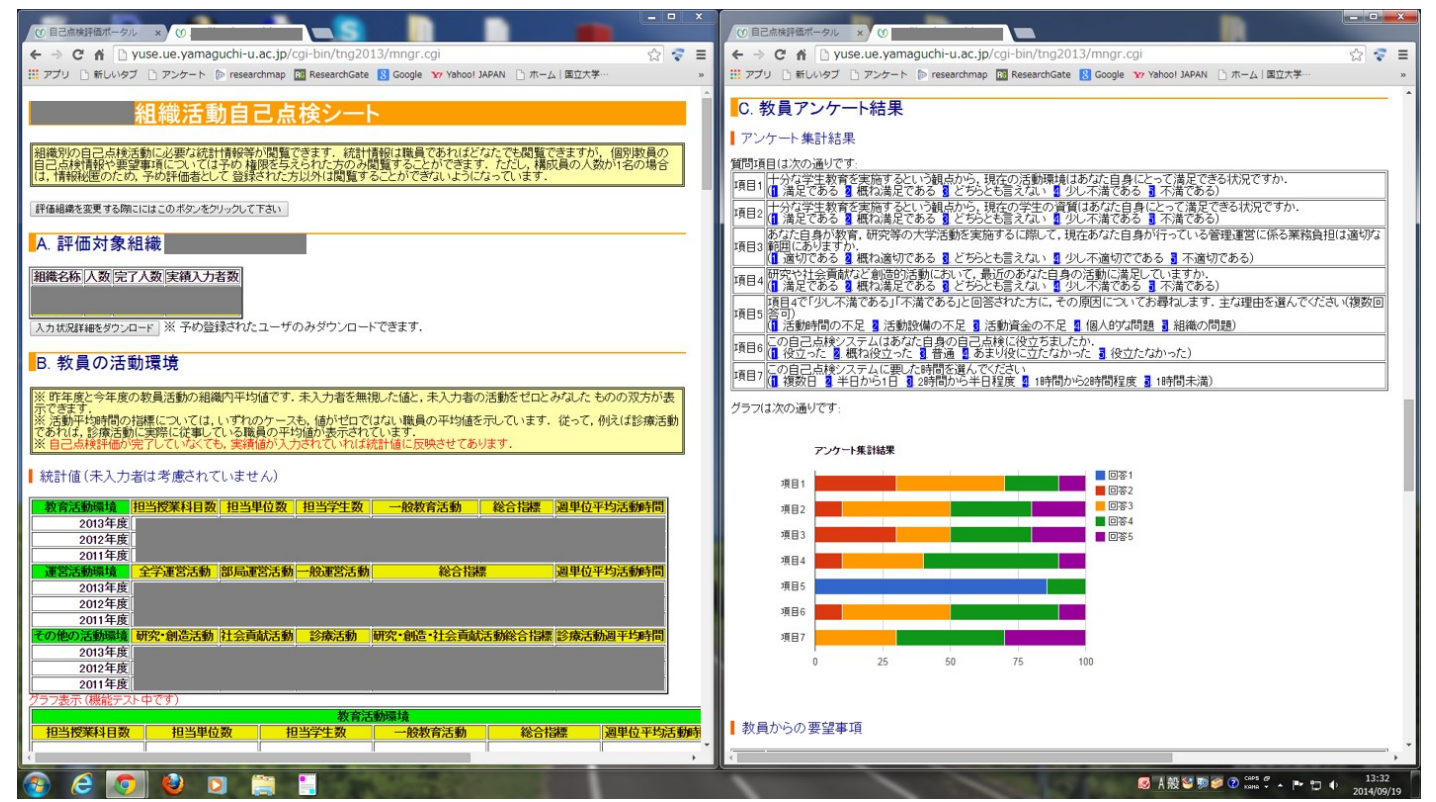

Figure 5: Screen capture of the organizational activities information aggregation system. 


\subsection{System for the self-assessment and evaluation of department chairs}

There is no change in the self-assessment and evaluation scheme by organization scheduled to be implemented in 2012, and the evaluation items consist of items criteria from organization-wise evaluation of certification conducted by National Institution for Academic Degrees and Quality Enhancement of Higher Education, institutional thematic assessment, items of the certified evaluation and accreditation for professional graduate schools, and items for self-assessment and evaluation. However, unlike the previous assessment process, those inputs are now supported by YUSE/TNG.

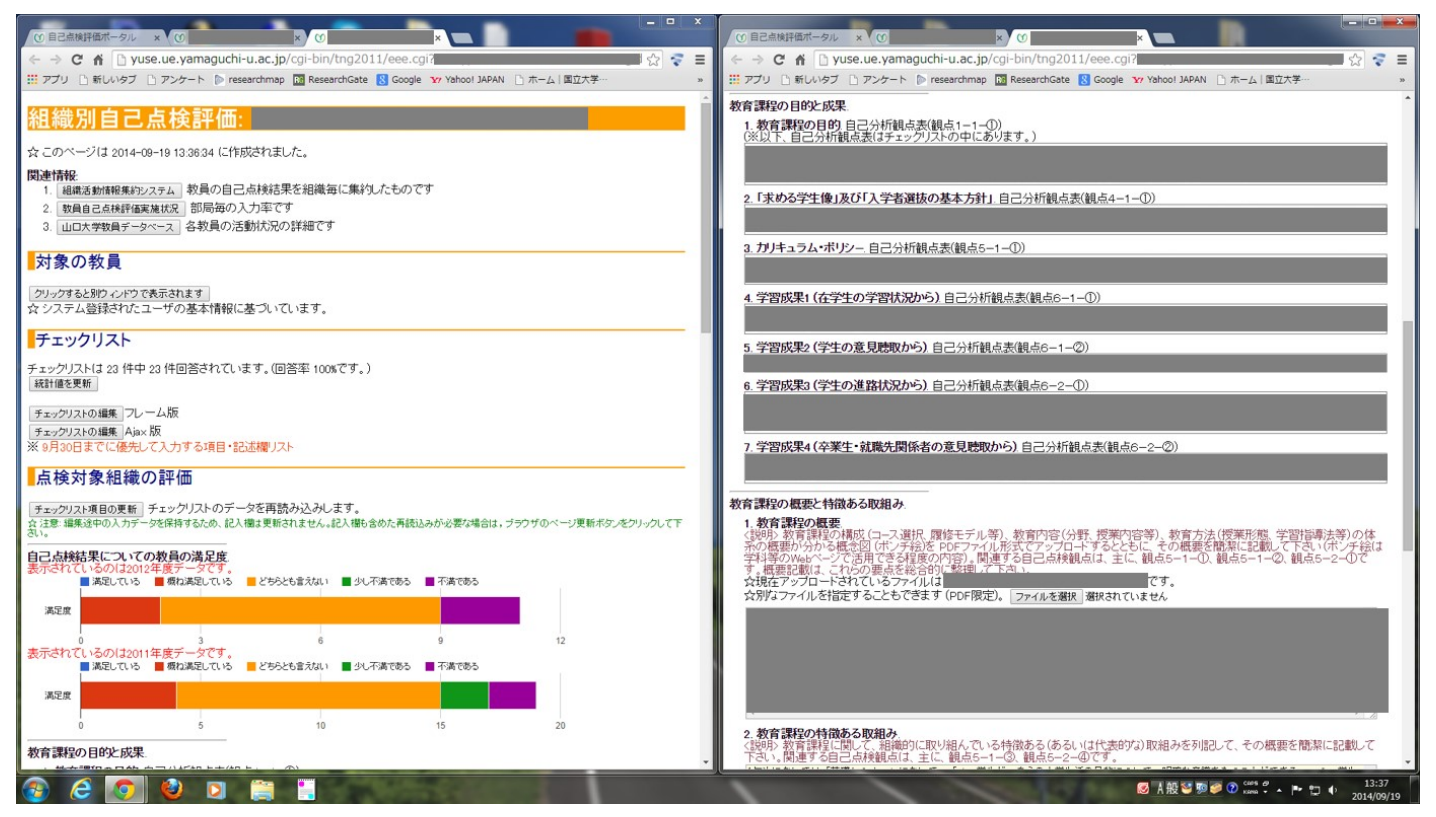

Figure 6: Organization-wise self-assessment and evaluation system input screen.

Figure 6 shows the page for organization-wise self-assessment and evaluation. The left side of Figure 6 contains basic information related to the department, such as links to the external information sources, a confirmation screen for the list of faculty members included in the department, and a link to the input screen of the checklist consisting of the table of self-analysis perspectives. In the right side, the goals of the educational curriculum are entered, and checklist contents are cited as necessary. Further, there are support functions for the sharing of entries by multiple persons-in-charge such as management functions of permissions to write, search function of editing conflicts using a time stamp, and a time warp function for editing past data. 


\subsection{Portal site}

In the new system, it is also true that compared to the previous system, aspects such as system linkage have become clearer. However, it is also accurate that some users are of the opinion that it is difficult to grasp such mutual correlations between systems. Therefore, the creation of a "self-assessment and evaluation portal" that compiles the entrance into various systems in one place was also being considered and was developed in the new system (Figure 7). This "self-assessment and evaluation portal" becomes an entrance to various systems from one location and thus plays an important role.

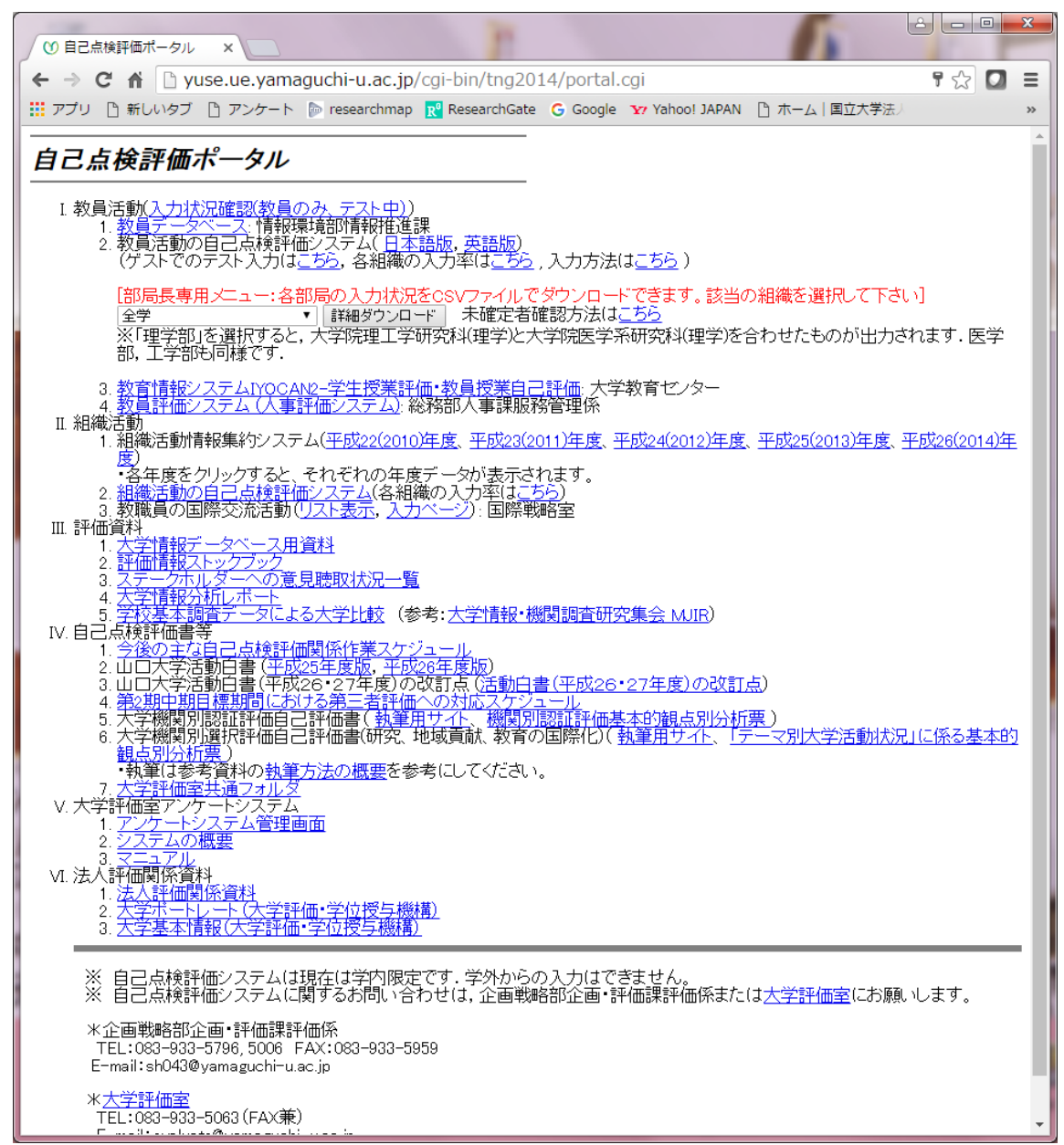

Figure 7: Screen capture of portal site. 


\section{Requests of the System Users}

Users noted that the system was generally difficult to use and that there were too many input items in place. They requested that the system be linked to other databases. Table 1 shows examples of user requests and the results of investigation into them.

Table1. Example user requests and the results of investigation into them. The category is described in Section 4.

\begin{tabular}{|c|c|c|c|}
\hline No. & User Requests & Results of Investigation & Category \\
\hline \multicolumn{4}{|c|}{ (1) System for the self-assessment and evaluation of faculty members } \\
\hline 1 & $\begin{array}{l}\text { I would like for you to } \\
\text { introduce an English-language } \\
\text { version for the non-Japanese } \\
\text { faculty members. }\end{array}$ & $\begin{array}{l}\text { To maintain both Japanese-language and } \\
\text { English-language input windows on the } \\
\text { website's "self-assessment and evalua- } \\
\text { tion portal". }\end{array}$ & $\bar{A}$ \\
\hline 2 & $\begin{array}{l}\text { I would like for faculty } \\
\text { members to be able to see their } \\
\text { input history when they input } \\
\text { data }\end{array}$ & $\begin{array}{l}\text { To add a function that allows users to } \\
\text { view data that they have input over the } \\
\text { previous year. }\end{array}$ & $\mathrm{A}$ \\
\hline 3 & $\begin{array}{l}\text { Faculty members want to ver- } \\
\text { ify their own input. }\end{array}$ & $\begin{array}{l}\text { To add a message function through } \\
\text { which each faculty member can verify } \\
\text { what they have or have not input. The } \\
\text { same function was added to another } \\
\text { evaluation system (the course-evaluation } \\
\text { system, IYOCAN2). }\end{array}$ & B \\
\hline 4 & $\begin{array}{l}\text { Please reconsider the details of } \\
\text { the input conditions so that } \\
\text { each department chair can } \\
\text { identify members who have not } \\
\text { recorded their data. }\end{array}$ & $\begin{array}{l}\text { To add a function for department chairs } \\
\text { so they can download files from the } \\
\text { website's "self-assessment and evalua- } \\
\text { tion portal" detailing the conditions of } \\
\text { their department's input }\end{array}$ & $\mathrm{A}$ \\
\hline \multicolumn{4}{|c|}{ (2) System for information on the organization's activities } \\
\hline 5 & $\begin{array}{l}\text { The graphs of change over time } \\
\text { are displayed in total amounts, } \\
\text { but I would like for the average } \\
\text { values to also be displayed. }\end{array}$ & $\begin{array}{l}\text { To add a function to display average } \\
\text { values in addition to showing total } \\
\text { amounts. }\end{array}$ & $\mathrm{C}$ \\
\hline \multicolumn{4}{|c|}{ (3) System for the self-assessment and evaluation of department chairs } \\
\hline 6 & $\begin{array}{l}\text { I would like to more easily } \\
\text { visualize self-assessment re- } \\
\text { sults on the organization's ac- } \\
\text { tivities. }\end{array}$ & $\begin{array}{l}\text { To add a function to display the results of } \\
\text { self-assessment of the organization's } \\
\text { activities on a radar chart. }\end{array}$ & $\mathrm{C}$ \\
\hline 7 & $\begin{array}{l}\text { I would like to compare this } \\
\text { year's faculty satisfaction level } \\
\text { with those of previous years. }\end{array}$ & $\begin{array}{l}\text { To add a function to display the general } \\
\text { satisfaction levels of faculty members (in } \\
\text { a bar chart) over a two-year period. }\end{array}$ & $\mathrm{C}$ \\
\hline
\end{tabular}




\section{Systematic Improvements and Their Consideration}

\subsection{Systematic improvement}

The present paper provides some examples of actual improvements to the system completed as a result of investigating user requests. Figure 8 shows a screenshot of the English version (Table 1 - No.1). Figure 9 shows a function to confirm input (Table 1 - No.3). Yamaguchi University owns some web systems for self-assessment; such as: the faculty database, self-assessment and evaluation system (the developed system), the course evaluation system (IYOCAN2), the personnel evaluation system, and so on. We developed a function to check whether faculty members entered their own data into each system or not. Figure10 shows a line chart function (Table 1 No.5). Figure 11 shows a radar chart function (Table 1 - No.6). Figure 12 shows a bar chart function (Table 1 - No.7). It is possible to categorize these improvements into three frameworks, according to the problem being improved: A. system usability (Table 1 - No.1, 2, and 4), B. links to other systems (Table 1 - No.3), C. visualization functions for analyses (graphs) (Table 1 - No. 5,6 , and 7). For A and C, the university can continue to make improvements as before, but for B, links to other systems are required, and therefore between-department collaboration is necessary. Improvements are difficult to make in category B, because there are various barriers in dealing with data from other departments.

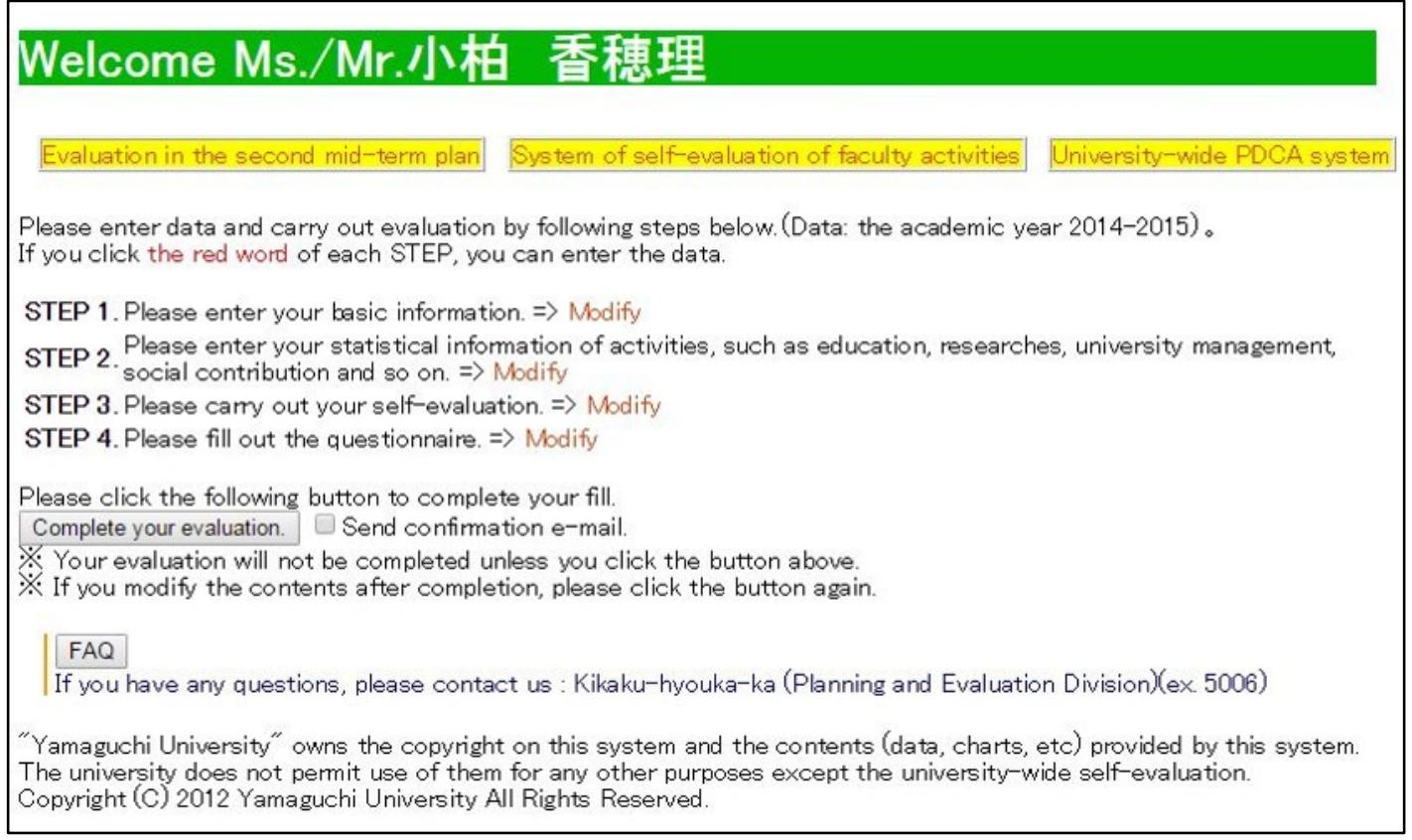

Figure 8: Screenshot of the English-language version of the system. 


\begin{tabular}{|c|c|c|c|}
\hline & 入力状况 & 期限 & 所管 \\
\hline 教員データベース & - & - & \begin{tabular}{|l} 
情報環境部 \\
情報推進課 \\
\end{tabular} \\
\hline $\begin{array}{l}\text { 教員活動の自己点検評価システ } \\
\text { ム(日，英) }\end{array}$ & ○(確定済) & 平成 27 年 9 月 30 日(水)まで & 大学評価室 \\
\hline $\begin{array}{l}\text { 教育情報システLIYOCAN2-学生 } \\
\text { 阌羓評価·教員授業自己評価 }\end{array}$ & 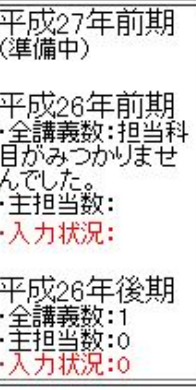 & 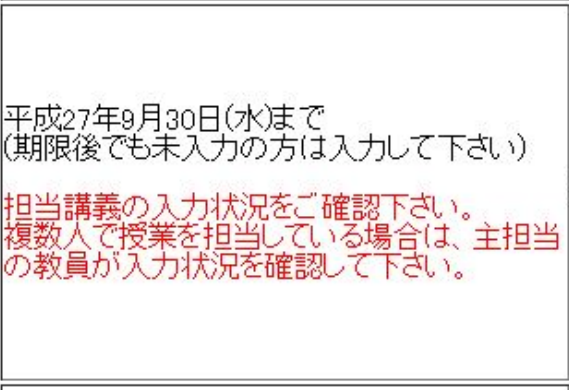 & 㚐学教育ゼ \\
\hline $\begin{array}{l}\text { 教員評価システム } \\
\text { 只) }\end{array}$ & - & - & \begin{tabular}{|l} 
戀務部人事 \\
課服務管理 \\
係
\end{tabular} \\
\hline
\end{tabular}

Figure 9: The function is used to confirm the input. This figure shows their own input result ( $\circ$ or $\times$ ) for faculty members about each system.

\begin{tabular}{|c|c|c|c|}
\hline Research activities & Journal & Book & Proceedings \\
\hline & 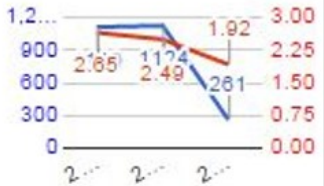 & 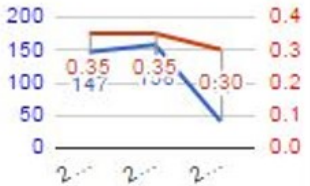 & 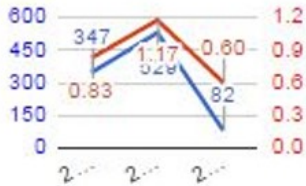 \\
\hline Research activities & Application & KAKENHI & Other grants \\
\hline & 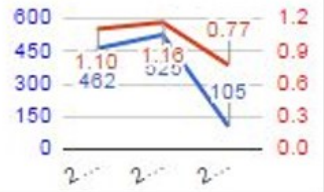 & 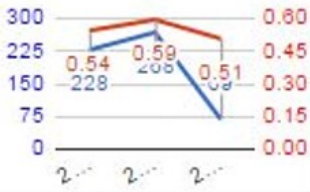 & 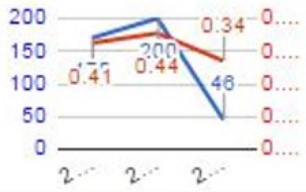 \\
\hline
\end{tabular}

Figure 10: System function displaying average change over time (red: average, blue: total). 


\section{Radar Chart Department A}

各基準において入力した点検評価の数値(達成度を表す数値:5段階評価)の平均を示しています。

\section{目的及乙管理迎党}

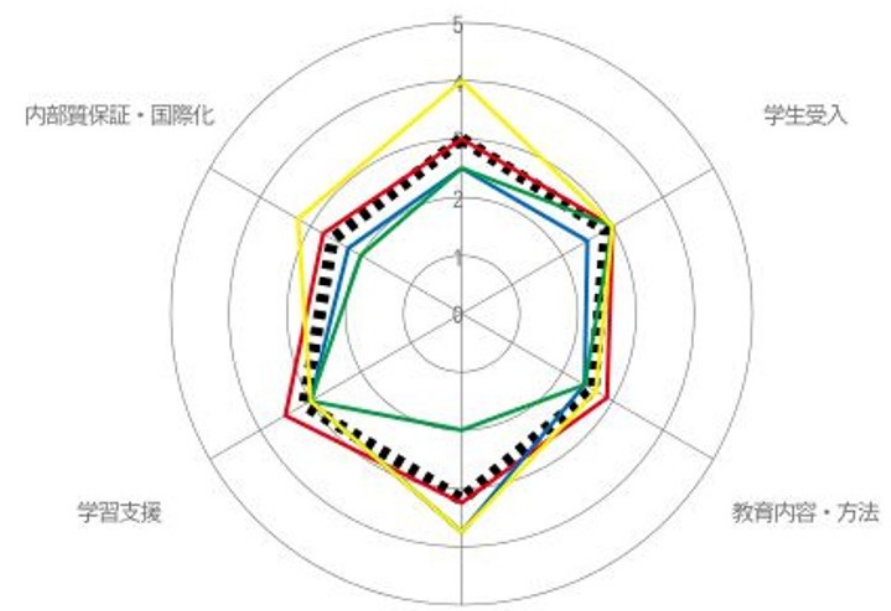

Average dotted tine

Department 1

Department 2

Department 3

Department 4

\section{学圆成果}

Figure 11: The radar chart function is used to compare departments. This figure shows the average of numerical input data (on a five-point scale). Each item conforms to the evaluation item (basic viewpoint) concerning institutional certified evaluation and accreditation.

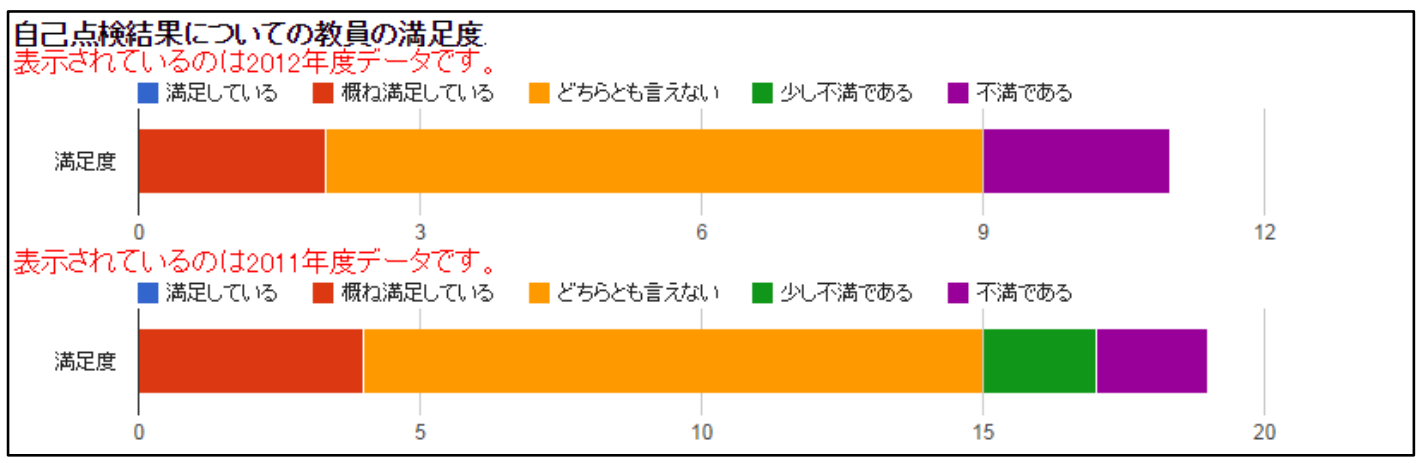

Figure 12: The bar chart function is used to compare with the previous year. This figure shows the general satisfaction levels of faculty members for the last two years. 


\subsection{Specific effects to university management using proposed systems}

We developed the three systems mentioned in Section 2 and constructed a systematic self-assessment and evaluation system using these systems to effectively practice the PDCA cycle. From fiscal year 2013, Yamaguchi University has conducted efficient annual self-assessments with the aid of the three systems. The main results obtained from the systems have been summarized in the Yamaguchi University Report every year. In addition, Yamaguchi University reorganizes the departments and restructures the curriculum based on the issues published in the Yamaguchi University Report. The above performance was reported as an outstanding activity in the results of the evaluation related to the second mid-term goals [10].

With regard to international standards in higher education, YUSE is not universally applicable because the education systems vary for every country. However, since the proposed system is simple, it is possible to respond flexibly by changing evaluation items. In this sense, the proposed system offers flexibility. An English version of the proposed system was developed by the authors of this study for the purpose of being used by internationalization of universities.

\section{Conclusion}

A number of enhancements were made to Yamaguchi University's self-assessment and evaluation system based on user requests. These improvements will be useful not only for Yamaguchi University, but also for other universities wishing to upgrade their evaluation systems. In comparison with Ref. [11], it is interesting that the support system of the evaluation process is largely similar, in spite of diversity in each university with respect to university evaluation.

We note that these system improvements can be categorized into three frameworks, depending upon the problem. Questions were raised, particularly for category B which concerned links to other systems. Questions included how data scattered across universities could be collected and organized and how major problems such as the collaboration and integration of various databases could be resolved to increase input efficiency. These issues should be investigated from the perspective of university evaluation and institutional research.

\section{Acknowledgments}

The new version of YUSE was developed by Professor Yoshihiko Ichikawa, who was, at that time, attached to the Yamaguchi University Media and Information Technology Center. The present study was carried out in cooperation with the course evaluation system (IYOCAN2) at Yamaguchi University. We sincerely thank Dr. Koichi Okada, Lecturer at Yamaguchi University for his assistance. This work was supported by JSPS KAKENHI Grant Number JP15K01071. We wish to thank all members of the university evaluation department of Yamaguchi University for their support. 


\section{References}

[1] J.L. Saupe, "Functions of Institutional Research," 2nd Edition, Association for Institutional Research, 1990.

[2] M. Mori, T. Oishi, and E. Takata, "University evaluation and instituional research" (in Japane se), IPSJ SIG Technical Report, vol.2015-CLE-15, no.3, 2015, pp.1-5.

[3] W. E. Knight, “The Primer for Institutional Research," Association for Institutional Rese arch, 2003.

[4] "University evaluation and institutional research" (in Japanese), IDE Higher Education Today, no.528, 2011

[5] "Grope for solutions to the problems facing IR" (in Japanese), IDE Higher Education To day, no. 586,2016

[6] Y. Ichikawa, K. Ogashiwa, M. Suzuki, T. Matsumoto, and H. Naitoh, "An overview of YUS E, Yamaguchi University Self-Evaluation System, in relation to university self-evaluation act ivities in the first mid-term goals period and the first half of the second period" (in Japanese), Journal for Academic Computing and Networking, no.16, 2012, pp.3-14.

[7] University Evaluation Department, Yamaguchi University, "Self-assessment and evaluation" (in Japanese), 6 April, 2017; http://committee.ue.yamaguchi-u.ac.jp/New_HomePage/jikoten nkennhyoka-system.html.

[8] FY 2015 Yamaguchi University Report (in Japanese), 6 April, 2017; http://committee.ue.yam aguchi-u.ac.jp/New_HomePage/27nenndo-hakusyo.pdf.

[9] Y. Ohira, K. Ogashiwa, S. Muranaga, T. Matsumoto, and H. Naitoh, "A questionnaire system for institutional research,” Information Engineering Express, vol.3, no.1, 2017, pp.9-18.

[10] The results of evaluation related to the second mid-term goals, Yamaguchi University, (in J apanese), 12 November, 2018; http://ds.cc.yamaguchi-u.ac.jp/ kikakuka/mokuhyo/dai2ki/01 _dai2ki_kekka.pdf.

[11] E Takata, "IR based on university evaluation" (in Japanese), IDE Higher Education Tod ay, no.528, 2011, pp.35-39. 